\title{
PENINGKATAN KREATIVITAS MELALUI MEDIA KERTAS KOKORU PADA ANAK USIA DINI DI TK KARTIKA XIX-43 CIMAHI
}

\author{
Sri Wulandari ${ }^{1}$, Arifah A. Riyanto ${ }^{2}$ \\ ${ }^{1}$ TK Kartika XIX-43 Cimahi \\ ${ }^{2}$ IKIP Siliwangi Bandung \\ 1'queenwulan83@gmail.com, ${ }^{2}$ arifahastim@yahoo.com
}

\begin{abstract}
This research stems from the concerns of researcher who see the less varied of the media used by the teacher when giving creativity learning to the students, in Kindergarten of Kartika XIX-43 Cimahi. This indicates not yet optimal learning by teachers in trying to increase creativity in students. Therefore, the aim of this researcher is to make changes by using kokoru paper media to improve the creativity of children of group B. and to describe the objective condition of learning in kindergarten of Kartika XIX-43 Cimahi, effort, and strategy, results achieved, and difficulties experienced by teachers on while learning creativity to improve children's creativity. As an educator of course must be much innovative and looking for a sharp strategy for learning creativity, because stimulates creativity early is very important to form a child more creative and independent to face his life that will come.
\end{abstract}

Keywords:Creativity, Kokoru Media Paper

\begin{abstract}
Abstrak
Penelitian ini bermula dari keprihatinan peneliti yang melihat kurang bervariatifnya media yang digunakan oleh guru pada saat memberi pembelajaran kreativitas pada anak didik, di TK Kartika XIX-43 Cimahi. Hal ini mengindikasikan belum optimalnya pembelajaran yang dilakukan guru dalam mengupayakan peningkatan kreativitas pada anak didik. Karena itu tujuan peneliti ini adalah ingin membuat perubahan dengan menggunakan media kertas kokoru untuk peningkatan kreativitas anak kelompok B. dan mendeskripsikan kondisi objektif pembelajaran di TK Kartika XIX-43 Cimahi, usaha, dan strategi, hasil yang dicapai, dan kesulitan yang dialami oleh guru pada saat pembelajaran kreativitas untuk meningkatkan kreativitas anak. Sebagai pendidik tentunya harus banyak berinovatif dan mencari strategi yang jitu untuk pembelajaran kreativitas, karena menstimulan kreativitas sejak dini sangatlah penting untuk membentuk anak lebih kreatif dan mandiri untuk menghadapi kehidupannya yang akan datang
\end{abstract}

Kata Kunci: Kreativitas, Media Kertas Kokoru 


\section{PENDAHULUAN}

Pada umumnya anak usia dini memiliki rasa ingin tahu yang besar dan kreativitas yang masih original. Setiap tingkah lakunya memiliki makna sebuah pembelajaran, kreativitas pada anak harus distimulan sejak dini karena akan menumbuhkan rasa percaya diri, kemandirian untuk mencurahkan segala ide dan imajinasi yang ada di pikirannya atau yang dikehendakinya.

Pada dasarnya manusia telah memiliki potensi kreatif sejak awal ia diciptakan. Potensi kreatif ini dapat kita lihat melalui keajaiban alamiah seorang bayi dalam mengeksplorasi apapun yang ada di sekitarnya. "all individuals are creative in diverse ways and different degrees" (Piers,1979, Dedi Supriadi,1994). Adalah pendidikan yang mengemban tugas untuk dapat mengembangkan potensi kreatif yang dimiliki manusia tersebut.

Kreativitas pada anak usia dini sangat perlu dibangkitkan atau distimulan dan dikembangkan dari dalam diri anak karena sangat penting untuk mewujudkan dirinya dengan berkreasi karena berkreasi dengan mewujudkan diri adalah salah satu kebutuhan pokok dalam kehidupan manusia.

Dalam mengembang kreativitas pada anak usia dini, perlu adanya ide kreativitas, penggunaan media yang bervariasi dari para pedidik, khususnya yang ada di TK Kartika XIX-43, agar pembelajaran tidak membosankan.

Penelitian ini bertujuan untuk mengetahui peningkatan kreatifitas melalui media kokoru pada anak usia dini di TK Kartika XIX-43 Cimahi.

\section{KAJIAN TEORI}

Kreativitas mengandung beberapa definisi, Lawrence (Suratno, 2003:24) menyatakan kreativitas merupakan ide atau pikiran manusia yang bersifat inovatif, berdaya guna, dan dapat dimengerti, sehingga hasil pikiran anak yang baru merupakan bentuk kreativitas dari individu anak. Sugiono (2005:134) meyakini bahwa kreativitas yang ditunjukkan anak merupakan bentuk kreativitas yang original dengan frekuensi kemunculannya seolah tanpa terkendali.

Suyatmi Munandar (Muharam, 1992:28) menyatakan bahwa kreativitas dapat dibedakan menjadi tiga yaitu: pertama, kemampuan untuk membuat baru, berdasarkan data, informasi, dan unsur-unsur yang ada (daya cipta). Kedua, kemampuan menggunakan data atau informasi yang tersedia. Ketiga, kemampuan yang mencerminkan kelancaran, keluwesan, kemurnian (keorisinilan).

Menurut James J. Gallagher mengatakan bahwa "creativity is a mental process by which an individual creates new ideas or product, or recombiesexisting ideas and product, in fashion that is novel to him or her" (kreativitas merupakan suatu proses mental yang dilakukan individu berupa gagasan ataupun produk baru, atau mengkombinasikan antara keduanya yang pada akhirnya akan melekat pada dirinya). Clarkl Montakis (dalam Rachmawati \& Kurniati,2010:13) mengatakan bahwa kreativitas merupakan pengalaman dalam mengekspresikan dan mengaktualisasikan identitas individu dalam bentuk terpadu antara hubungan diri sendiri, alam, dan orang lain. Pada umumnya definisi kreativitas dirumuskan dalam istilah pribadi (person), proses, produk dan press, seperti yang diungkapkan oleh Rhodes yang menyebut hal ini sebagai "four $P$ 's of Creativity: Person, Process, Press, Product". Keempat P ini saling berkaitan: Pribadi yang kreatif yang melibatkan diri 
dalam proses kreatif, dan dengan dukungan dan dorongan (press) dan lingkungan, akan menghasilkan produk kreatif.

Dari paparan dapat disimpulkan bahwa kreativitas adalah pemikiran atau ide yang inovatif yang menghasilkan suatu produk atau hasil karya baru atau yang di kolaborasikan yang mencermin kan keluwesan, kelancaran, kemurnian (keorisinilan).

Dari paparan dapat disimpulkan bahwa kreativitas adalah ide-ide kreatif yang sangat orisinil yang melibatkan imajinasi dari seseorang untuk menciptakan suatu hasil karya yang baru.

\section{A. Pengertian Kreativitas}

Kreativitas adalah kemampuan untuk membuat kombinasi baru, berdasarkan data, informasi, atau unsur-unsur yang ada. Kreativitas dalam pendidikan anak usia dini sangat penting perlu dipupuk dan dikembangkan dalam diri anak yaitu pertama, karena berkreasi orang dapat mewujudkan dirinya, dan perwujudan diri termasuk salah satu kebutuhan pokok dalam kehidupan manusia. Unsur unsur kretivitas sebagai berikut: 1). Imajinatif, 2). Mempunyai prakarsa, 3). Mempunyai minat luas, 4). Mandiri dalam berpikir, 5). Senang berpetualang, 6). Penuh energi, 7). Percaya diri, 8). Bersedia mengambil resiko, 9). Berani dalam pendirian dan keyakinan.

Dengan potensi kreativitas alami yang dimilikinya, maka anak akan senantiasa membutuhkan aktivitas yang syarat dengan ide-ide kreatif. Mereka perlu mendapatkan pembinaan yang tepat yang kemampuannya itu secara optimal, yang

\section{B. Ciri-Ciri Kreativitas Anak}

Ciri-ciri kreativitas anak menurut pendapat Suyatmi Munandar (2009:71) meliputi:

1) Rasa ingin tahu yang luas dan mendalam.

2) Sering mengajukan pertanyaan yang baik.

3) Memberikan banyak gagasan atau usul terhadap suatu masalah.

4) Bebas dalam menyatakan pendapat.

5) Mempunyai rasa keindahan yang dalam.

6) Menonjol dalam salah satu bidang seni.

7) Mampu melihat suatu masalah dari berbagai segi/sudut pandang.

8) Mempunyai rasa humor yang luas.

9) Mempunyai daya imajinasi.

10) Orisinal dalam ungkapan gagasan dan dalam pemecahan masalah.

Ciri-ciri kreativitas anak dapat diketahui melalui pengamatan terhadap perilaku anak yang berbeda dengan anak pada umumnya. Perbedaan perilaku anak tersebut biasanya membuat orangtua cemas dan bagi orang tua yang belum memahami tentang ciri-ciri anak kreatif biasanya menganggap anak nakal. Pada akhirnya diharapkan kemampuannya tersebut dapat berguna bagi dirinya, keluarga, dan masyarakat luas pada umumnya.

Adapun indikator-indikator dalam kreativitas menurut beberapa ahli (Munandar, 2009:37): Beberapa faktorfaktor yang dapat mempengaruhi kreativitas yaitu: 1). Faktor internal: a). kemampuan intelektual, b). komitmen, c). penguasaan, d). intuisi, 2). Faktor eksternal: a). lingkungan keluarga, b). lingkungan sekolah, c). lingkungan masyarakat.

\section{Pengembangan Kreativitas Anak \\ Pengembangan \\ kreativitas \\ keterampilan anak TK adalah atau}




\section{JURNAL CERIA}

ISSN : 2614-6347 (Print) 2614-4107 (Online)

Vol.1 | No.3 | Mei 2018

kemampuan untuk menciptakan (Depdiknas, 2005:38) menurut Suyatmi Munandar (1999:45-46) kreativitas paling penting untuk dipupuk dan dikembangkan melalui pendidikan sejak usia dini dengan alasan karena orang dapat mewujudkan dirinya. Seorang ahli, Maslow (Suyatmi Munandar, 1999:46), menyebutkan bahwa kreativitas merupakan manifestasi dari individu yang berfungsi sepenuhnya dalam perwujudan dirinya. Selain itu kreativitas dapat memberikan kepuasan terhadap individu serta dengan kreativitas memungkinkan manusia untuk meningkatkan kualitas hidupnya.

Pada masa ini anak akan mudah menyerap kesan, pengetahuan, keteladanan yang terjadi di lingkungannya seperti spon yang menyerap air. Fase ini membuat anak akan mudah menyerap kesan apa pun yang terjadi, termasuk kesannya terhadap aktivitas belajar. Jika para pendidik gagal memberikan kesan positif terhadap aktivitas belajar, maka anak akan membeci proses belajar sampai tua. Namun, jika para pendidik berhasil menanamkan kesan positif pada anak, maka anak akan menyukai proses belajar hingga dewasa. Proses pembelajaran yang menjemukan, terlalu mudah ataupun terlalu sulit, membuat anak merasa capek, terlalu banyak menuntut, tidak menghargai keunikan dan perbedaan anak, memaksakan kehendak guru, ketat aturan yang tidak perlu, hingga anak mogok sekolah, dapat menciptakan kesan yang negatif. Sedangkan proses belajar yang menyenangkan, diminati anak, membuat anak antusias, tertawa-tawa, banyak bertanya hingga akhirnya enggan pulang ke rumah, menunjukkan kita berhasil menciptakan kesan yang positif tentang belajar.

Untuk mempertahankan daya kreatif, para pendidik harus memperhatikan sifat natural anak yang sangat menunjang tumbuhnya kreativitas. Sifat-sifat natural yang mendasar inilah yang harus senantiasa dipupuk dan dikembangkan, sehinga sifat kreatif mereka tidak hilang.

Dibawah ini merupakan sifat natural anak yang mendasar yang sangat menunjang tumbuhnya kreativitas, sebagai berikut:

1) Pesona dan rasa takjub

2) Mengembangkan imajinasi

3) Rasa Ingin Tahu

4) Banyak Bertanya

\section{Strategi Peningkatan Kreativitas Anak Usia Dini}

Dalam garis-garis besar program kegiatan belajar taman kanak-kanak 1994 disebutkan bahwa pengembangan daya cipta adalah kegiatan yang bertujuan untuk membuat anak kreatif, yaitu lancar, fleksibel dan orisinal, dalam bertutur kata, berfikir serta berolah tangan dan berolah tubuh sebagai latihan motorik halus dan motorik kasar. Oleh karena itu, daya cipta harus ada dalam pengembangan bahasa, daya pikir, keteramplan dan jasmani.

Berkenaan dengan perkembangan kreativitas di sekolah, kurikulum berbasis kompetensi menegaskan bahwa para siswa memiliki potensi untuk berbeda. Perbedaan siswa terlihat dalam pola pikir, daya imajinasi, fantasi (pengandaian) dan hasil karyanya. Akibatnya kegiatan belajar mengajar perlu dipilih dan dirancang agar memberikan kesempatan dan kebebasan berkreasi secara berkesinambungan untuk mengembangkan dan mengoptimalkan kreativitas siswa. Berdasarkan hal tersebut diatas maka berikut ini akan dikemukan strategi pengembangan kreativitas pada anak usia taman kanak-kanak.

Pengembangan kreativitas pada anak melalui kegiatan hasta karya ini memiliki posisi penting dalam berbagai aspek perkembangan anak. Tidak hanya kreativitas yang akan terfasilitasi untuk berkembang dengan baik, tetapi juga kemampuan kognitif anak. Dalam kegiatan 
hastakarya setiap anak akan menggunakan imajinasinya untuk membentuk suatu bangun atau benda tertentu sesuai dengan khayalannya. Dalam pembuatannya pun mereka menggunakan berbagai bahan yang berbeda. Setiap anak bebas mengekspresikan kreativitasnya, sehingga kita akan memperoleh hasil yang berbeda antara satu anak dan anak lainnya. Mungkin kita akan menemui anak yang membangun gedung pencakar langit dari topless kue, membuat terowongan dari dus, membuat rumah dari tanah liat, menggambarmatahari dengan telinga lebar, membuat ikan dari kertas kokoru. Pada dasarnya hasil karya anak yang dibuat melalui aktivitas membuat, menyusun atau mengkonstruksi ini akan memberikan kesempatan bagi anak untuk menciptakan benda buatan mereka sendiri yang belum pernah mereka temui, atau pun mereka membuat modifikasi dari benda yang telah ada sebelumnya. Apapun yang dibuat oleh anak akan membantu mereka menjadi lebih kreatif dan semangat untuk menemukan sesuatu yang baru.

\section{E. Teori Kreativitas}

\section{Teori Wallas}

Dikemukakan tahun 1926 dalam buku The Art of Thought (Piirto, 1992) menyatakan bahwa proses kreatif meliputi empat tahap.
a. Tahap persiapan.
b. Tahap inkubasi.
c. Tahap iluminasi.
d. Tahap verifikasi.

\section{Teori persimpangan kreativitas (creativity Intersection)}

Keberhasilan kreatif adalah persimpangan (intersection) antara keterampilan anak dalam bidang tertentu (domain skills).

Keterampilan berpikir dan bekerja kreatif, dan motivasi intrinsik, dapat juga disebut motivasi batin (Amabile,
1989). Motivasi intrinsik sebagaimana telah dikemukakan adalah motivasi yang tumbuh dari dalam, berbeda dengan motivasi ekstrinsik yang ditimbulkan dari luar oleh lingkungan seperti dijelaskan dalam gambar berikut.

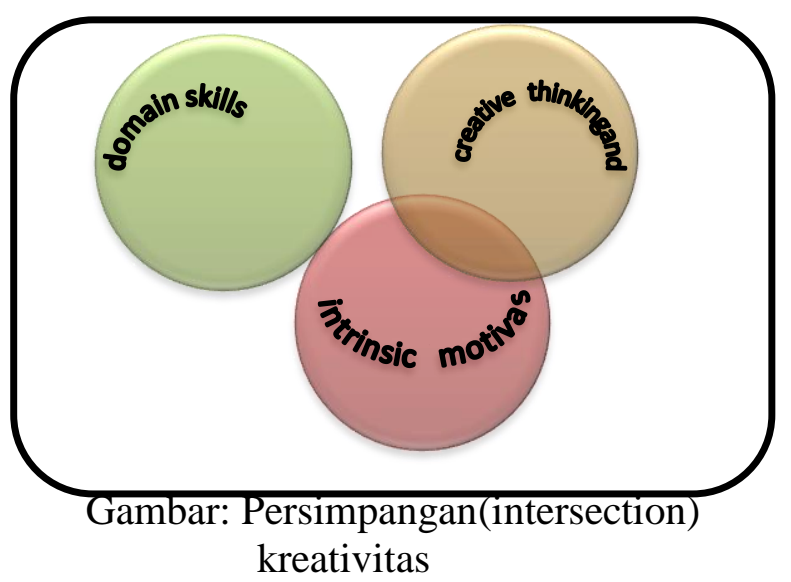

\section{F. Pengertian Media Kertas Kokoru}

Apa itu media kertas kokoru? Komponen kertas Kokoru paper atau kertas kokoru singkatan dari CO-lor CORRU-gated paper, yang artinya kertas berwarna yang gelombang atau kertas gelombang warna. Kokoru merupakan jenis kertas bergelombang yang biasa digunakan untuk bagian tengah dari kardus. Melihat kegunaan dan manfaat dalam hobi dan kreativitas, Indah Kiat Paper mengembangkan kertas kokoru menjadi sebuah kertas dengan warna warni yang menarik, kokoru bisa dijadikan bahan untuk berkreasi khususnya dalam seni Quiling (menggulung kertas) dan origami (melipat kertas). Perpaduan kedua seni dan hobi dalam mengolah kertas kokoru menghasilan suatu kreasi berbentuk animasi dalam imajinasi. Dengan kertas kokoru, kreasi kertas bisa diaplikasikan secara 2 dimensi dan 3 dimensi. Kertas kokoru memliki beberapa jenis dari beberapa warna diantaranya kokoru ichi, ichigo, ichiro, dan kokoru hachi, hachigo dan Hachiro. 
Kertas kokoru ini adalah kertas asli Indonesia, sudah ada sejak 2-3 tahun yang lalu. Kokoru ini sudah diproduksi secara masal dan diekspor hingga ke jepang. Kertas kokoru ini di produksi oleh PT. Indah Kiat Pulp \& Paper Tbk. yang merupakan salah satu perusahaan di grup Asia Pulp \& Paper (APP). Kertas ini menurut Yuki M.A Wardhana (GM Corporate Governance and Social Responsibility Asia Pulp \& Paper) bertujuan untuk menumbuhkan kreativitas otak kanan, terutama untuk anak-anak taman kanak-kanak (TK) dan sekolah dasar (SD).

\section{METODE PENELITIAN}

Pendekatan penelitiandalamskripsi iniadalahpendekatankualitatif. Fokus dalam penelitian ini adalah anak kelompok B TK Kartika XIX-43 Cimahi, berjumlah 21 anak yang terdiri dari 7 orang laki-laki dan 14 orang perempuan, yang rata-rata berumur 5-6 tahun.

Metodepengumpulan data yang digunakan antara lain: observasi, dokumentasi dan study literature. Teknis analisis data menggunakan model analisis interaktif dengan langkah analisis mulai dari pengumpulan data ,reduksi data, penyajian data sampai penarikan kesimpulan.

\section{PEMBAHASAN PENELITIAN}

\section{Langkah-Langkah Kegiatan Penelitian}

\section{Di kelompok B TK Kartika XIX-43 Cimahi}

\begin{tabular}{lll}
\hline $\begin{array}{l}\text { Pertemuan } \\
\text { ke } 1\end{array}$ & $\begin{array}{l}\text { Pertemuan } \\
\text { ke } 2\end{array}$ & $\begin{array}{l}\text { Pertemuan } \\
\text { ke 3 }\end{array}$ \\
$\begin{array}{l}\text { Hari\&tgl: } \\
\text { Selasa, 13 }\end{array}$ & $\begin{array}{l}\text { Hari\&tgl: } \\
\text { Selasa, 20 }\end{array}$ & $\begin{array}{l}\text { Hari\&tgl: } \\
\text { Selasa, 27 }\end{array}$
\end{tabular}

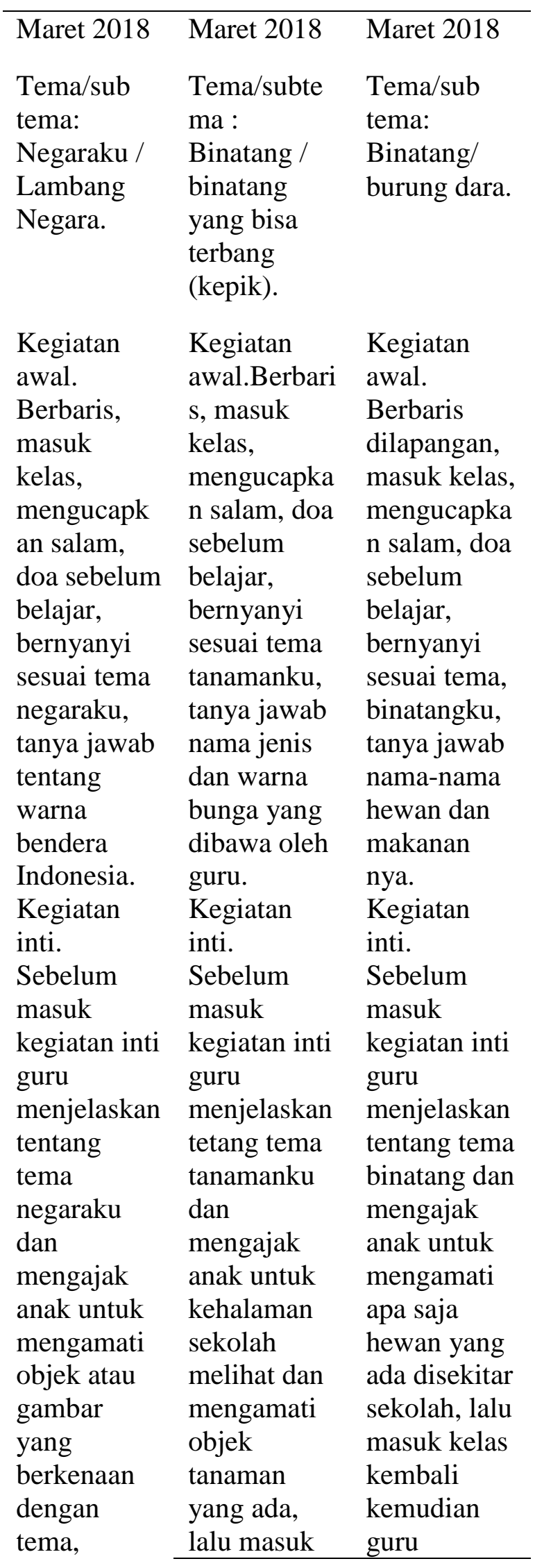


Vol.1 | No.3 | Mei 2018

\begin{tabular}{|c|c|c|c|c|c|}
\hline $\begin{array}{l}\text { kemudian } \\
\text { guru } \\
\text { menjelaskan } \\
\text { tentang cara } \\
\text { membuat } \\
\text { hasta karya } \\
\text { dari media } \\
\text { kertas } \\
\text { kokoru yang } \\
\text { benar sesuai } \\
\text { dengan apa } \\
\text { yang anak } \\
\text { lihat. } \\
\text { Setelah } \\
\text { selesai } \\
\text { membuat } \\
\text { bendera } \\
\text { dengan } \\
\text { menggunak } \\
\text { an media } \\
\text { kertas } \\
\text { kokoru anak } \\
\text { anak maju } \\
\text { kedepan } \\
\text { menceritaka } \\
\text { n hasil } \\
\text { karyanya } \\
\text { yang di } \\
\text { buatnya. } \\
\text { Kegiatan } \\
\text { istirahat. } \\
\text { Pada } \\
\text { kegiatan ini, } \\
\text { setelah anak } \\
\text { selesai } \\
\text { melakukan } \\
\text { tugas yang } \\
\text { diberikan } \\
\text { guru, anak- } \\
\text { anak } \\
\text { diperbolehk } \\
\text { an untuk } \\
\text { mencuci } \\
\text { tangan,doa } \\
\text { makan, } \\
\text { makan } \\
\text { bersama }\end{array}$ & $\begin{array}{l}\text { kelas } \\
\text { kembali } \\
\text { kemudian } \\
\text { guru } \\
\text { menjelaskan } \\
\text { tentang } \\
\text { pembelajara } \\
\text { n kreativitas } \\
\text { menggunaka } \\
\text { n media } \\
\text { kertas } \\
\text { kokoru. } \\
\text { Guru } \\
\text { menjelaskan } \\
\text { langkah- } \\
\text { langkah } \\
\text { membuat } \\
\text { tanaman dari } \\
\text { bunga, daun, } \\
\text { batang dan } \\
\text { pot, anak } \\
\text { anak diberi } \\
\text { media kertas } \\
\text { kokoru yang } \\
\text { sudah ada } \\
\text { pola untuk } \\
\text { di gunting, } \\
\text { gulung atau } \\
\text { lipat. Setelah } \\
\text { anak-anak } \\
\text { menyelesaik } \\
\text { an tugas } \\
\text { yang } \\
\text { diberikan } \\
\text { guru, anak- } \\
\text { anak } \\
\text { menjelaskan } \\
\text { apa yang } \\
\text { dibuatnya } \\
\text { dan warna } \\
\text { kertas yang } \\
\text { dipakainya. } \\
\text { Kegiatan } \\
\text { istirahat. } \\
\text { Pada } \\
\text { kegiatan ini, } \\
\text { setelah anak }\end{array}$ & $\begin{array}{l}\text { menjelaskan } \\
\text { tentang } \\
\text { pembelajara } \\
\text { n kreativitas } \\
\text { menggunaka } \\
\text { n media } \\
\text { kertas } \\
\text { kokoru. guru } \\
\text { menjelaskan } \\
\text { langkah- } \\
\text { langkah } \\
\text { yang } \\
\text { dilakukan } \\
\text { untuk } \\
\text { membuat } \\
\text { binatang } \\
\text { darimedia } \\
\text { kertas } \\
\text { kokoru. } \\
\text { Setelah } \\
\text { anak-anak } \\
\text { melakukan } \\
\text { dan } \\
\text { menyelesaik } \\
\text { an tugasnya, } \\
\text { anak-anak } \\
\text { menjelaskan } \\
\text { hasil karya } \\
\text { yang di } \\
\text { buatnya dan } \\
\text { warna kertas } \\
\text { yang } \\
\text { digunakan. } \\
\text { Kegiatan } \\
\text { istirahat. } \\
\text { Pada } \\
\text { kegiatan ini, } \\
\text { setelah anak } \\
\text { selesai } \\
\text { melakukan } \\
\text { tugas yang } \\
\text { diberikan } \\
\text { guru, anak- } \\
\text { anak } \\
\text { diperbolehka } \\
\text { n mencuci } \\
\text { tangan lalu }\end{array}$ & $\begin{array}{l}\text { setelah } \\
\text { selesai lalu } \\
\text { berdoa } \\
\text { sesudah } \\
\text { makan, dan } \\
\text { bermain } \\
\text { bersama. } \\
\text { Kegiatan } \\
\text { penutup. } \\
\text { Pada } \\
\text { kegiatan } \\
\text { penutup } \\
\text { anak-anak } \\
\text { diajak tanya } \\
\text { jawab } \\
\text { tentang } \\
\text { kegiatan } \\
\text { yang telah } \\
\text { di pelajari } \\
\text { dan } \\
\text { memberikan } \\
\text { informasi } \\
\text { tentang hari } \\
\text { esok, } \\
\text { berdoa } \\
\text { sebelum } \\
\text { pulang dan } \\
\text { salam. }\end{array}$ & $\begin{array}{l}\text { selesai } \\
\text { melakukan } \\
\text { tugas yang } \\
\text { diberikan } \\
\text { guru, anak- } \\
\text { anak } \\
\text { diperbolehka } \\
\text { n untuk } \\
\text { mencuci } \\
\text { tangan, doa } \\
\text { sebelum } \\
\text { makan, } \\
\text { makan } \\
\text { bersama } \\
\text { setelah } \\
\text { selesai } \\
\text { makan } \\
\text { bersama lalu } \\
\text { doa sesudah } \\
\text { makan dan } \\
\text { bermain } \\
\text { bersama } \\
\text { Kegiatan } \\
\text { oenutup. } \\
\text { Pada kegiatan } \\
\text { penutup } \\
\text { guru } \\
\text { menanyakan } \\
\text { perasaan } \\
\text { anak-anak } \\
\text { setelah } \\
\text { semua } \\
\text { kegiatan } \\
\text { sekolah } \\
\text { berlangsung, } \\
\text { dan } \\
\text { melakukan } \\
\text { tanya jawab } \\
\text { tentang } \\
\text { kegiatan } \\
\text { yang telah } \\
\text { dipelajari } \\
\text { dan } \\
\text { memberikan } \\
\text { informasi } \\
\text { untuk esok } \\
\text { hari, doa }\end{array}$ & $\begin{array}{l}\text { doa sebelum } \\
\text { makan dan } \\
\text { makan } \\
\text { bersama } \\
\text { setelah } \\
\text { selesai } \\
\text { makan } \\
\text { bersama } \\
\text { anak-anak } \\
\text { diperbolehka } \\
\text { n main } \\
\text { bersama di } \\
\text { area } \\
\text { bermain. } \\
\text { Kegiatan } \\
\text { penutup. } \\
\text { Pada } \\
\text { kegiatan } \\
\text { penutup } \\
\text { guru } \\
\text { menanyakan } \\
\text { perasaan } \\
\text { anak-anak } \\
\text { setelah } \\
\text { melakukan } \\
\text { kegiatan } \\
\text { pembelajara } \\
\text { n selama di } \\
\text { sekolah dan } \\
\text { melakukan } \\
\text { tanya jawab } \\
\text { tentang } \\
\text { kegiatan } \\
\text { yang sudah } \\
\text { dipelajari } \\
\text { dan } \\
\text { memberikan } \\
\text { informasi } \\
\text { untuk esok } \\
\text { hari. }\end{array}$ \\
\hline
\end{tabular}


setelah

belajar dan

pulang.

\section{Observasi}

Pada saat kegiatan proses belajar berlangsung, guru mengadakan observasi yaitu mengamati secara langsung kegiatan anak dan guru kemudian mengadakan evaluasi. Penggunaan sistem evaluasi yang bersifat menyeluruh untuk menentukan kualitas dari suatu program atau kemajuan dari seseorang anak. Evaluasi merupakan upaya memperoleh informasi mengenai kreativitas dan potensi individu dengan dua sasaran yaitu sasaran pertama memberikan umpan balik yang bermanfaat kepada anak yang bersangkutan, sasaran kedua sebagai data yang berguna bagi masyarakat yang disekitarnya.

\section{HASIL DAN PEMBAHASAN \\ Hasil Peningkatan Kreativitas Anak Melalui Media Kertas Kokoru Di TK Kartika XIX-43 Cimahi}

\footnotetext{
Selanjutnya meningkatkan kreativitas anak melalui media kertas kokoru mengalami peningkatan yang signifikan seperti pada saat guru memberikan pembelajaran keterampilan/kreativitas, anak terlihat antusias, aktif dalam mengikuti kegiatan keterampilan tersebut. Kreativitas menggunakan media kokoru ini melatih motorik halus dan motorik kasar anak, juga menstimulan kognitif, sosial emosional, norma agama dan moral, dan seni pada anak. Anak melakukan kegiatan kreativitas tanpa bantuan orang dewasa melalui berbagai macam kegiatan seperti, melipat, menggunting, menggulung, mengelem, menempel.

Dari sejumlah anak yang mengikuti kegiatan kreativitas/keterampilan dengan
}

menggunakan media kertas kokoru tersebut beberapa anak belum mengalami peningkatan kreativitas dikarenakan berbagai faktor diantaranya faktor kebiasaan dalam keluarganya, kurangnya perhatian orang tua yang menyebabkan kurangnya bimbingan dan latihan tentang kreativitas anak, anak diberi smartphone agar anak duduk dan diam hal ini menyebabkan anak menjadi kurang kreatif, jarang menggerakan tubuh karena duduk terus menerus. Dan juga kurangnya motivasi kepada anak sebelum kegiatan dilaksanakan, terbukti masih ada anak yang awalnya terpaksa mengikuti kegiatan tersebut.

Dalam hal kreativitas anak-anak harus diberikan kebebasan, kesempatan untuk mencoba, melakukan mengkreasikan segala imajinasi keinginannya sendiri walaupun hasilnya belum maksimal, akan tetapi anak harus terbiasa melakukannya, sehingga anak mulai terbiasa dan dapat mengekspresikan ide kreativitasnya sendiri, diperlukan kerjasama antara pengelola lembaga, pendidik, dan orang tua murid yang sangat mempengaruhi aspek-aspek perkembangan anak terutama aspek kreativitas anak. Dengan demikian kreativitas anak dapat meningkat dengan maksimal, baik dirumah maupun di sekolah.

Data instrumen observasi digunakan untuk hasil peningkatan kreativitas peserta didik. Instrumen observasi ditujukan untuk peserta didik dan guru yang menjadi sampel dalam penelitian ini dengan menggunakan perbandingan dari hasil karya peserta didik di setiap pertemuan. Peneliti mengobservasi anak pada saat kegiatan berlangsung. Instrumen observasi yang digunakan berupa data ceklis BB (Belum Berkembang), MB (Mulai Berkembang), BSH (Berkembang Sesuai Harapan). Berikut di sajikan data 


\section{JURNAL CERIA}

ISSN : 2614-6347 (Print) 2614-4107 (Online)

Vol.1 | No.3 | Mei 2018

instrument observasi untuk anak yang telah di analisis pada table.

\section{Data Instrumen Observasi}

\section{Peningkatan Kreativitas Melalui Media}

Kertas Kokoru Pada Anak Usia Di

TK Kartika XIX-43 Cimahi

\begin{tabular}{|c|c|c|c|c|c|c|c|c|}
\hline \multirow[t]{2}{*}{ No. } & \multirow{2}{*}{$\begin{array}{l}\text { Nama } \\
\text { Anak }\end{array}$} & \multirow{2}{*}{$\begin{array}{c}\text { No. } \\
\text { Item } \\
\text { Pertan } \\
\text { yaan }\end{array}$} & \multicolumn{2}{|l|}{ BB } & \multicolumn{2}{|c|}{$\overline{\text { MB }}$} & \multicolumn{2}{|c|}{ BSH } \\
\hline & & & $\begin{array}{l}\mathbf{J} \\
\mathbf{m} \\
\mathbf{l}\end{array}$ & $\%$ & $\begin{array}{l}\mathbf{J} \\
\mathrm{m} \\
\mathrm{l}\end{array}$ & $\%$ & $\begin{array}{l}\mathbf{J} \\
\mathbf{m} \\
\mathbf{l}\end{array}$ & $\%$ \\
\hline 1 & Azmi & $1-25$ & 0 & 0 & 3 & $\begin{array}{c}\frac{3}{25} \times 100 \\
=12\end{array}$ & $\begin{array}{l}2 \\
2\end{array}$ & $\begin{array}{l}\frac{22}{25} \times 100 \\
=88\end{array}$ \\
\hline 2 & Aiko & $1-25$ & 0 & 0 & 0 & 0 & $\begin{array}{l}2 \\
5\end{array}$ & $\begin{array}{l}\frac{25}{25} \times 100 \\
=100\end{array}$ \\
\hline 3 & Dimas & $1-25$ & 0 & 0 & 0 & 0 & $\begin{array}{l}2 \\
5\end{array}$ & $\begin{array}{l}\frac{25}{25} \times 100 \\
=100\end{array}$ \\
\hline 4 & Kaila & $1-25$ & 0 & 0 & 4 & $\begin{array}{l}\frac{4}{25} \\
\times 100 \\
=16\end{array}$ & $\begin{array}{l}2 \\
1\end{array}$ & $\begin{array}{l}\frac{21}{25} \times 100 \\
=84\end{array}$ \\
\hline 5 & Naira & $1-25$ & 0 & 0 & 3 & $\begin{array}{l}\frac{3}{25} \\
\times 100 \\
=12\end{array}$ & $\begin{array}{l}2 \\
2\end{array}$ & $\begin{array}{l}\frac{22}{25} \times 100 \\
=88\end{array}$ \\
\hline 6 & Nabila & $1-25$ & 0 & 0 & $\begin{array}{l}1 \\
1\end{array}$ & $\begin{array}{l}\frac{11}{25} \\
\times 100 \\
=44\end{array}$ & $\begin{array}{l}1 \\
4\end{array}$ & $\begin{array}{l}\frac{14}{25} \times 100 \\
=56\end{array}$ \\
\hline 7 & Afiqa & $1-25$ & 0 & 0 & 8 & $\begin{array}{l}\frac{8}{25} \\
\times 100 \\
=32\end{array}$ & $\begin{array}{l}1 \\
7\end{array}$ & $\begin{array}{l}\frac{17}{25} \times 100 \\
=68\end{array}$ \\
\hline 8 & Ratih & $1-25$ & 0 & 0 & 4 & $\begin{array}{l}\frac{4}{25} \\
\times 100 \\
=16\end{array}$ & $\begin{array}{l}2 \\
1\end{array}$ & $\begin{array}{l}\frac{21}{25} \times 100 \\
=84\end{array}$ \\
\hline 9 & Reyhan & $1-25$ & 0 & 0 & 8 & $\begin{array}{l}\frac{8}{25} \\
\times 100 \\
=32\end{array}$ & $\begin{array}{l}1 \\
7\end{array}$ & $\begin{array}{l}\frac{17}{25} \times 100 \\
=68\end{array}$ \\
\hline 10 & Yashira & $1-25$ & 0 & 0 & 0 & 0 & $\begin{array}{l}2 \\
5\end{array}$ & $\begin{array}{l}\frac{25}{25} \times 100 \\
=100\end{array}$ \\
\hline 11 & Shyla & $1-25$ & 0 & 0 & 0 & 0 & $\begin{array}{l}2 \\
5\end{array}$ & $\begin{array}{l}\frac{25}{25} \times 100 \\
=100\end{array}$ \\
\hline 12 & Kanaya & $1-25$ & 0 & 0 & 0 & 0 & $\begin{array}{l}2 \\
5\end{array}$ & $\begin{array}{l}\frac{25}{25} \times 100 \\
=100\end{array}$ \\
\hline 13 & $\begin{array}{l}\text { Hasya } \\
\text { Amelia }\end{array}$ & $1-25$ & 0 & 0 & 0 & 0 & $\begin{array}{l}2 \\
5\end{array}$ & $\begin{array}{l}\frac{25}{25} \times 100 \\
=100\end{array}$ \\
\hline
\end{tabular}

Ket: Item pertanyaan terlampir di instrumen observasi.
Hasil Penelitian Peningkatan

Kreativitas Melalui Media Kertas

Kokoru Di TK Kartika XIX-43 Cimahi

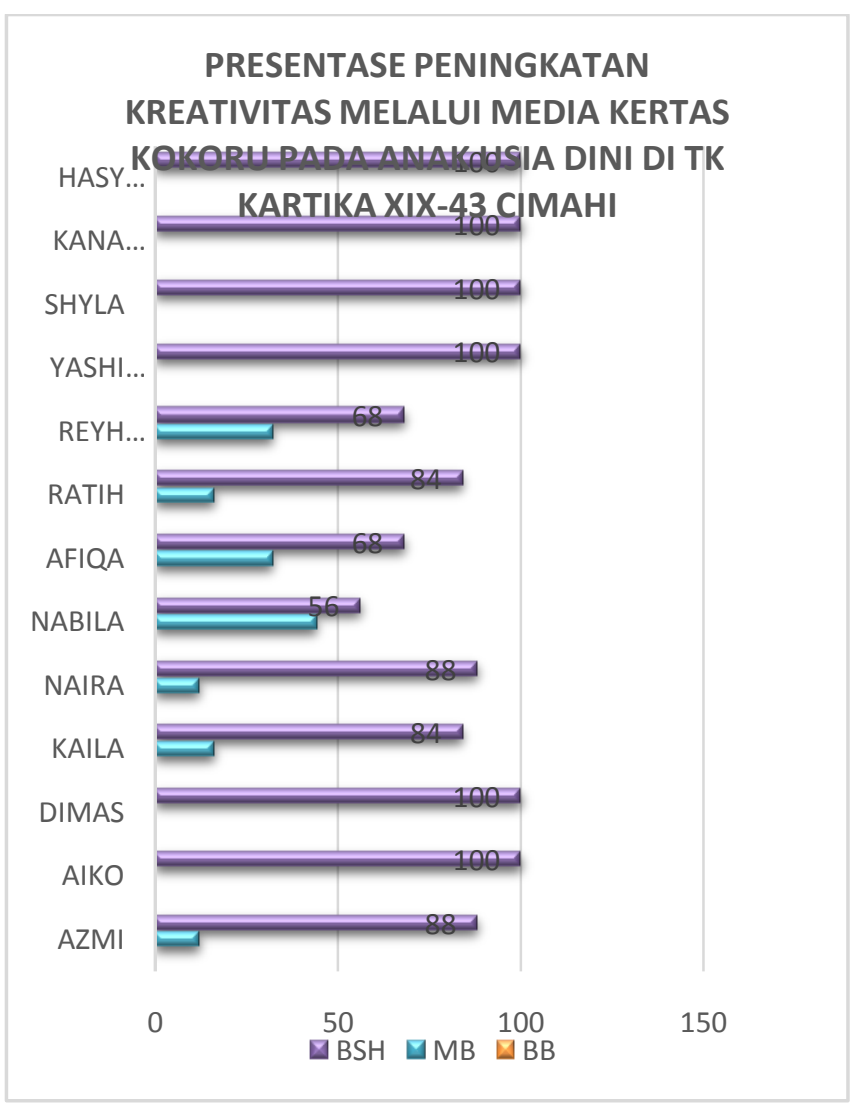

G. Kegiatan Hasil Perencanaan dan Pelaksanaan Peningkatan Kreativitas

Dalam pembelajaran peningkatan kretivitas melalui media kertas kokoru, sebelum memulai pembelajaran guru menyusun RPPM dan RPPH disertai penilaiannya, menyusun kegiatan yang akan dilakukan untuk menstimulan 


\section{JURNAL CERIA}

ISSN : 2614-6347 (Print) 2614-4107 (Online)

Vol.1 | No.3 | Mei 2018

peningkatan kreativitas melalui media

kertas kokoru guru menentukan aspek perkembangan anak agar pembelajaran peningkatan kreativitas melalui media kertas kokoru berjalan efektif dan menunjukkan hasil, selain guru menentukan aspek perkembangan guru juga menyediakan alat dan bahan seperti memilih jenis media kertas kokoru, gunting, lem yang akan digunakan oleh anak-anak dalam pembelajaran kreativitas.

Pada saat pagi hari sebelum dimulainya pembelajaran guru sudah mempersiapkan situasi dan kondisi kelas yang bersih, nyaman dan menarik bagi anak agar pembelajaran berjalan dengan kondusif. Ibu guru mempersiapkan berbagai keperluan yang akan digunakan untuk pembelajaran pada hari tersebut. Dan juga mempersiapkan alat dan bahan untuk pembelajaran peningkatan kreativitas dengan media kertas kokoru.

Konsep dasar kreativitas dalam peningkatan kreativitas anak merupakan proses berulang yang dilakukan secara bertahap dalam mencurahkan ide dan gagasan dalam bentuk hasil karya seni. Proses peningkatan kreativitas sering juga dikaitkan dengan beberapa aspek perkembangan anak. Kreativitas merupakan salah satu media untuk anak mencurahkan ide atau gagasannya dan imajinasinya dalam bentuk hasil karya. Dalam pelaksanaan pembelajaran peningkatan kreativitas melalui media kertas kokoru pada anak usia dini di TK Kartika XIX-43 Cimahi harus ada perencanaan yang sesuai teknik dan instrumen yang tepat agar mendapatkan hasil yang maksimal. pembelajaran dilakukan untuk melihat perkembangan anak secara keseluruhan yang meliputi enam aspek nilai agama dan norma, fisik motorik, Bahasa, kognitif, sosial emosional, seni. Pembelajaran kreativitas dilakukan untuk mengukur proses pembelajaran sejauh mana pembelajaran itu telah dicapai.

Pada dasarnya guru telah melaksanakan langkah-langkah proses kegiatan pembelajaran tersebut sesuai dengan standar pendidikan yang tercantum dalam Permendikbud nomor 146 tahun 2014 tentang kurikulum 2013, karakterisitik kurikulum

\section{Kondisi anak sebelum mendapatkan pembelajaran kreativitas melalui media kertas kokoru}

Kondisi anak sebelum guru memberikan pembelajaran kreativitas melalui media kertas kokoru untuk dijadikan peningkatan kreativitas anak dapat terlihat beberapa item indikator pertanyaan yang dijadikan bahan observasi. 
a. Aspek sosial emosional memperlihatkan kemampuan diri untuk menggunakan kertas kokoru. Pada kegiatan sehari-hari, anak-anak kurang merespon dengan baik untuk kegiatan kreativitas dan kurang memperlihatkan kemampuan diri untuk membuat kreativitas sesuai dengan imajinasinya.

b. Aspek bahasa mampu berkomunikasi secara lisan dengan kalimat sederhana pada aspek bahasa anak kurang mampu mengatakan secara lisan apa ide yang anak miliki.

c. Aspek kognitif (belajar memecahkan masalah) pada aspek tersebut sebagian murid masih belum bisa memecahkan masalah yang dihadapinya terbukti pada beberapa anak jika mengalami kesulitan atau kendala anak tersebut akan langsung berteriak memanggil ibu guru dan meminta membantunya.

d. Aspek kognitif (berpikir logis) pada aspek tersebut anak belum berpikir logis artinya berpikir dengan menggunakan logika, rasional dan masuk akal.

e. Aspek kognitif (mengetahui bermacam warna) pada aspek tersebut anak masih suka tertukar menyebutkan warna.

f. Aspek fisik motorik (mampu menggunakan alat untuk mengeksplorasi dan mengekspresikan diri dalam berbagai bentuk) pada aspek tersebut anak belum mahir menggunaan alat dan media yang diberikan oleh guru.

g. Aspek fisik motorik (menggunting, menggulung, menempel pola) pada aspek tersebut anak belum bisa menggunting, menggulung, menempel sesuai dengan gambar pola yang ada dengan tepat. h. Aspek sosial emosional (memahami peraturan dan disiplin) pada aspek tersebut anak masih banyak yang belum disiplin dan melanggar aturan yang diberikan oleh guru.

i. Aspek seni (dapat mengekspresikan imajinasinya dalam bentuk karya seni kreativitas dengan menggunakan kertas kokoru) pada aspek tersebut anak belum dapat mengekspresikan imajinasinya dalam bentuk karya seni kreativitas menggunakan kertas kokoru.

\section{Kondisi Anak Setelah Mendapatkan Pembelajaran Kreativitas Melalui Media Kertas Kokoru}

Kondisi anak setelah guru memberikan pembelajaran kreativitas melalui media kertas kokoru untuk dijadikan peningkatan kreativitas anak dapat terlihat beberapa item indikator pertanyaan yang dijadikan bahan observasi.

a. Aspek sosial emosional (memperlihatkan kemampuan diri untuk menggunakan kertas kokoru). Hasil observasi pada aspek tersebut anak-anak kelas B merespon dengan baik dengan rasa senang untuk memulai pembelajaran kreativitas melalui media kertas kokoru.

b. Aspek bahasa (mampu berkomunikasi secara lisan dengan kalimat sederhana). Hasil observasi pada aspek tersebut anak-anak kelas B sudah mulai berani berkomunikasi dengan baik dan dapat mengeluarkan apa yang dia mau.

c. Aspek kognitif (belajar memecahkan masalah). Hasil observasi pada aspek tersebut anak-anak kelas B sudah mulai dapat belajar memecahkan masalah yang dihadapinya, 
contohnya saat mereka kesulitan untuk menggulung kertas tidak sesuai dengan pola yang ada mereka berusaha semaksimal mungkin mengikuti pola yang ada, walaupun asil nya tetap belum sesuai dengan pola yang ada.

d. Aspek kognitif (berpikir logis). Hasil observasi pada aspek tersebut anakanak kelas B sudah mulai dapat berpikir logis sesuai dengan usianya.

e. Aspek kognitif (mengetahui bermacam warna). Hasil observasi pada aspek tersebut anak-anak kelas B sudah mulai mengingat dengan baik warna- warna yang ditunjukkan oleh guru atau yang mereka lihat dengan baik.

f. Aspek fisik motorik (mampu menggunakan alat untuk mengeksplorasi dan mengekspresikan diri dalam berbagai bentuk). Hasil observasi pada anak-anak kelas B sudah mampu dan berani mengeksplorasi di sekitar dan mengekspresikannya.

g. Aspek fisik motorik (menggunting, menggulung, menempel pola). Hasil observasi pada anak-anak kelas B sudah mulai mahir menggunakan gunting, kertas kokoru, lem dengan baik dan secara hati-hati.

h. Aspek sosial emosional (memahami peraturan dan disiplin). Hasil observasi pada anak-anak kelas B sudah dapat memahami peraturan yang dibuat bersama-sama dengan konsekuensi yang sudah ditetapkan bersama jika melanggar.

i. Aspek seni (dapat mengekspresikan imajinasinya dalam bentuk karya seni kreativitas dengan menggunakan kertas kokoru). Hasil observasi pada anak-anak kelompok B sudah dapat menuangkan idenya untuk memilih warna kertas dan membuat sesuatu dari media kertas kokoru.

Berdasarkan semua data diatas, disimpulkan bahwa peningkatan kreativitas anak usia dini menggunakan media kertas kokoru di TK Kartika XIX43 Cimahi sudah mulai berhasil. Data tersebut menunjukkan bahwa sebagian besar anak sudah mampu melakukan kegiatan pembelajaran yang dapat meningkatkan kreativitas mereka seperti terdapat pada indikator-indikator dibawah ini:

a. Memperlihatkan kemampuan diri untuk menggunakan kertas kokoru.

b. Mampu berkomunikasi secara lisan dengan kalimat sederhana.

c. Belajar memecahkan masalah.

d. Berpikir logis.

e. Mengetahui bermacam warna.

f. Mampu menggunakan alat untuk mengeksplorasi dan mengekspresikan diri dalam berbagai bentuk.

g. Menggunting, menggulung, menempel pola

h. Memahami peraturan dan disiplin.

i. Dapat mengekspresikan imajinasinya dalam bentuk karya seni kreativitas dengan menggunakan kertas kokoru.

\section{KESIMPULAN}

Berdasarkan hasil penelitian dan pembahasan, dapat disimpulkan beberapa hal mengenai pembelajaran kreativitas dengan menggunakan media kertas kokoru untuk meningkatkan kreativitas anak di TK Kartika XIX-43 Cimahi, maka dapat disimpulkan dari pernyataan penelitian sebagai berikut:

1. Perencanaan kegiatan pembelajaran kreativitas dengan media keratas kokoru dalam peningkatan kreativitas 


\section{JURNAL CERIA}

ISSN : 2614-6347 (Print) 2614-4107 (Online)

Vol.1 | No.3 | Mei 2018

sudah terencana dengan baik, guru mempersiapkan rencana pembelajaran seperti RRPM, RPPH dan media kertas kokoru dan kondisi kelas yang nyaman dan menyenangkan sebelum di mulai nya kegiatan kreativitas sesuai dengan tema/subtema.

2. Pelaksanaan pembelajaran kreativitas dengan menggunakan media kertas kokoru berjalan lancar, guru memberikan informasi dengan jelas dan detail, memberikan langkah-langkah atau contoh menggunakan media kertas kokoru pada anak-anak sebelum berlangsungnya kegiatan pembelajaran kreativitas dengan media kertas kokoru.

3. Hasil kreativitas anak berkreasi dengan menggunakan media kertas kokoru sangat berdampak pada peningkatan kreativitas anak di TK Kartika XIX-43 Cimahi. Hal tersebut dapat dilihat dari beberapa indikator penilaian kreativitas anak sebelum dan sesudah pembelajaran kreativitas dengan menggunakan media kertas kokoru menunjukan perkembangan yang optimal.Bahwa dengan menggunakan media kertas kokoru memberikan anak pengalaman baru dan kesempatan untuk berkreativitas dengan media yang baru, sebagian besar anak sudah berhasil sesuai harapan.

\section{DAFTAR PUSTAKA}

Sugiono.

(2015)

Metode pendidikan.Bandung : Alfabeta

Rachmawati, Y., \& Kurniati,E (2010) Strategi Pengembangan Kreativitas Pada Anak Usia Taman Kanak-Kanak.Bandung

Suyatmi, Jurnal Meningkatkan Kreativitas Anak Usia Dini Melalui Aktivitas Menggambar Pada Anak Kelompok A di TK ABA Ngabean 2 


\section{JURNAL CERIA}

ISSN : 2614-6347 (Print) 2614-4107 (Online)

Vol.1 | No.3 | Mei 2018 